慶應義塾大学学術情報リポジトリ

Keio Associated Repository of Academic resouces

\begin{tabular}{|c|c|}
\hline Title & Nucleotides bearing a cleavable genotoxic group on the phosphate \\
\hline \multicolumn{2}{|l|}{ Sub Title } \\
\hline Author & $\begin{array}{l}\text { 早津, 彦哉(Hayatsu, Hikoya) } \\
\text { 明石，牧子(Akashi, Makiko) } \\
\text { 稲田, 直美(Inada, Naomi) } \\
\text { 高島, 征助(Takashima, Seisuke) } \\
\text { 石川，さと子(Ishikawa, Satoko) } \\
\text { 膝舘, 祥治(Hizatate, Shoji) } \\
\text { 望月, 正隆(Mochizuki, Masataka) }\end{array}$ \\
\hline Publisher & 共立薬科大学 \\
\hline Publication year & 1993 \\
\hline Jtitle & $\begin{array}{l}\text { 共立薬科大学研究年報 (The annual report of the Kyoritsu College of } \\
\text { Pharmacy). No.38 (1993. ), p.72- } 72\end{array}$ \\
\hline \multicolumn{2}{|l|}{ JaLC DOI } \\
\hline \multicolumn{2}{|l|}{ Abstract } \\
\hline Notes & 抄録 \\
\hline Genre & Technical Report \\
\hline URL & $\begin{array}{l}\text { https://koara.lib.keio.ac.jp/xoonips/modules/xoonips/detail.php?koara_id=AN00062898-0000003 } \\
\text { 8-0072 }\end{array}$ \\
\hline
\end{tabular}

慶應義塾大学学術情報リポジトリ(KOARA)に掲載されているコンテンツの著作権は、それぞれの著作者、学会または出版社/発行者に帰属し、その権利は著作権法によって 保護されています。引用にあたっては、著作権法を遵守してご利用ください。

The copyrights of content available on the KeiO Associated Repository of Academic resources (KOARA) belong to the respective authors, academic societies, or publishers/issuers, and these rights are protected by the Japanese Copyright Act. When quoting the content, please follow the Japanese copyright act. 


\title{
Nucleotides Bearing a Cleavable Genotoxic Group on the Phosphate*
}

\author{
Hikoya Hayatsu**, Makiko Axashi**, Naomi InadA**, Seisuke Takashima***, \\ Satoko Ishikawa, Shoji Hizatate and Masataka Mochizuki \\ 早津彦哉**, 明石牧子**, 稲田直実 ${ }^{* *}$, 高島征助 ${ }^{* * *}$, 石川さと子, 膝舘祥治, 望月正隆
}

$N$-Nitrosopyrrolidine (NPYR), a rodent carcinogen, is a promutagen requiring enzymic conversion, presumably to its $\alpha$-hydroxylated derivative, to exhibit its mutagenic activity. Earlier studies from our laboratory have shown that NPYR and N-nitrosomorpholine can be converted into their $\alpha$-phosphate esters on near-ultraviolet (UVA) irradiation in the presence of inorganic phosphate and that these $\alpha$-phosphate derivatives are directly mutagenic toward bacteria. Furthermore, direct mutagenicity was observed for UVAirradiated mixtures of $N$-nitrosomorpholine and nucleotides (in place of inorganic phosphate), and the mutagenic components formed were found in distinctive zones in paper chromatography depending on the nucleotides linked to the $N$-nitrosodialkylamine at the $\alpha$-carbon. Such compounds seemed to be worthy of exploration for their properties. We report here the synthesis of this new class of nucleotide derivatives by the reaction with NPYR. These nucleotides are directly mutagenic to Salmonella, and they can be cleaved in vitro under mild conditions at the phosphoester-NPYR linkage. The product, thymidine 5'-phosphate mono(1-nitroso-2'-pyrrolidinyl)ester, was isolated by use of TLC on cellulose followed by paper chromatography. The NMR spectra $\left({ }^{1} \mathrm{H},{ }^{31} \mathrm{P},{ }^{1} \mathrm{H}-{ }^{1} \mathrm{H}\right.$ COSY, and ${ }^{1} \mathrm{H}-{ }^{31} \mathrm{H}$ HSQC) of this material supported the expected structure and its diastereomeric mixture. The proton-detected ${ }^{1} \mathrm{H}-{ }^{31} \mathrm{P}$ heteronuclear two-dimensional correlation spectrum $\left({ }^{1} \mathrm{H}-{ }^{31} \mathrm{P}\right.$ HSQC) confirmed the assignment that the phosphate is linked to the $\alpha$-carbon of NPYR. With near-ultraviolet irradiation, this cleavage takes place and, when a strand of DNA is present in the reaction mixture, the DNA undergoes single strand breaks.

The NPYR moiety may be incorporated into oligonucleotides having terminal phosphomonoester groups. Such oligonucleotides would be useful in specific cleavage of nucleic acids and in targeted gene-manipulation. This new class of nucleotide derivatives may also be useful in studies of mutagenesis and carcinogenesis mechanisms of $N$-nitrosodialkylamines. 2-Butenal, and moiety from the NPYR nucleotides, should be reactive not only to DNA but also to nucleophilic groups in proteins and other biological substances.

* 本報告は J. Am. Chem. Soc., 115 (3)，1180-1181（1993）に発表。

** 岡山大学薬学部

*** 岡山大学地域共同研究センター 